\title{
Front Matter: Volume 10089
}

, "Front Matter: Volume 10089," Proc. SPIE 10089, Real-time Measurements, Rogue Phenomena, and Single-Shot Applications II, 1008901 (5 April 2017); doi: $10.1117 / 12.2276092$

SPIE. Event: SPIE LASE, 2017, San Francisco, California, United States 


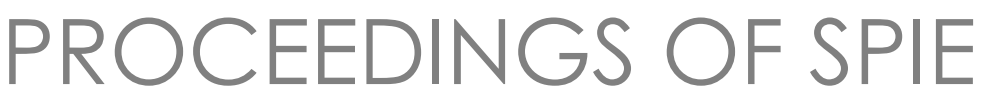

\title{
Real-time Measurements, Rogue Phenomena, and Single-Shot Applications II
}

\author{
Bahram Jalali \\ Daniel R. Solli \\ Sergei K. Turitsyn \\ Günter Steinmeyer \\ Neil G. R. Broderick \\ Editors
}

30-31 January 2017

San Francisco, California, United States

Sponsored and Published by

SPIE 
The papers in this volume were part of the technical conference cited on the cover and title page. Papers were selected and subject to review by the editors and conference program committee. Some conference presentations may not be available for publication. Additional papers and presentation recordings may be available online in the SPIE Digital Library at SPIEDigitallibrary.org.

The papers reflect the work and thoughts of the authors and are published herein as submitted. The publisher is not responsible for the validity of the information or for any outcomes resulting from reliance thereon.

Please use the following format to cite material from these proceedings:

Author(s), "Title of Paper," in Real-time Measurements, Rogue Phenomena, and Single-Shot Applications II, edited by Bahram Jalali, Daniel R. Solli, Sergei K. Turitsyn, Günter Steinmeyer, Neil G. R. Broderick, Proceedings of SPIE Vol. 10089 (SPIE, Bellingham, WA, 2017) Seven-digit Article CID Number.

ISSN: 0277-786X

ISSN: 1996-756X (electronic)

ISBN: 9781510606197

ISBN: 9781510606203 (electronics)

Published by

SPIE

P.O. Box 10, Bellingham, Washington 98227-0010 USA

Telephone +1 3606763290 (Pacific Time) · Fax +1 3606471445

SPIE.org

Copyright (@) 2017, Society of Photo-Optical Instrumentation Engineers.

Copying of material in this book for internal or personal use, or for the internal or personal use of specific clients, beyond the fair use provisions granted by the U.S. Copyright Law is authorized by SPIE subject to payment of copying fees. The Transactional Reporting Service base fee for this volume is $\$ 18.00$ per article (or portion thereof), which should be paid directly to the Copyright Clearance Center (CCC), 222 Rosewood Drive, Danvers, MA 01923. Payment may also be made electronically through CCC Online at copyright.com. Other copying for republication, resale, advertising or promotion, or any form of systematic or multiple reproduction of any material in this book is prohibited except with permission in writing from the publisher. The CCC fee code is 0277-786X/17/ \$18.00.

Printed in the United States of America.

Publication of record for individual papers is online in the SPIE Digital Library.

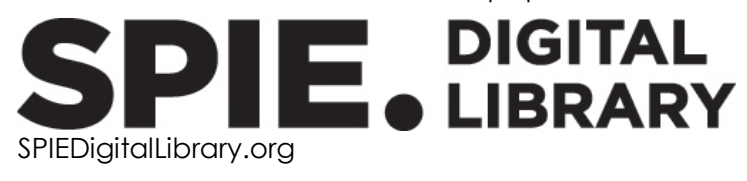

Paper Numbering: Proceedings of SPIE follow an e-First publication model. A unique citation identifier (CID) number is assigned to each article at the time of publication. Utilization of CIDs allows articles to be fully citable as soon as they are published online, and connects the same identifier to all online and print versions of the publication. SPIE uses a seven-digit CID article numbering system structured as follows:

- The first five digits correspond to the SPIE volume number.

- The last two digits indicate publication order within the volume using a Base 36 numbering system employing both numerals and letters. These two-number sets start with 00, 01, 02, 03, 04, 05, $06,07,08,09,0 A, O B \ldots$. OZ, followed by 10-1Z, 20-2Z, etc. The CID Number appears on each page of the manuscript. 


\title{
Contents
}

\author{
$\checkmark$ Authors \\ vii Conference Committee
}

\section{SESSION $1 \quad$ LASER TRANSIENTS AND ELECTRON BEAM DYNAMICS}

1008902 Unveiling relativistic electron bunch microstructures and their dynamical evolutions, using photonic time-stretch (Invited Paper) [10089-7]

1008903 Single-shot observation of optical rogue waves in integrable turbulence using time microscopy (Invited Paper) [10089-2]

1008905 Single-shot spectroscopy of broadband Yb fiber laser (Invited Paper) [10089-4]

1008907 Hidden amplitude-phase correlations in the carrier-envelope noise of mode-locked lasers (Invited Paper) [10089-6]

\section{SESSION 2 REAL-TIME TECHNIQUES}

1008909 Optical pulse waveform profiling through real-time stamping to corresponding characteristic spectra (Invited Paper) [10089-8]

10089 OA Billion frames per second spectrum measurement for high-repetition-rate optical pulses based on time stretching technique (Invited Paper) [10089-9]

$10089 \mathrm{OB}$ Real-time spatiotemporal measurement of ultrafast fields from multimode optical fibers (Invited Paper) [10089-10]

\section{SESSION $3 \quad$ PHOTON DOPPLER VELOCIMETRY AND RANGING}

10089 OF Broadband laser ranging development at the DOE Labs (Invited Paper) [10089-14]

10089 OG Broadband laser ranging: signal analysis and interpretation (Invited Paper) [10089-15]

$10089 \mathrm{OH} \quad$ Velocity measurement using frequency domain interferometer and chirped pulse laser (Invited Paper) [10089-16]

\section{SESSION 4 NONLINEAR DYNAMICS AND MEASUREMENTS I}

10089 ol Spatiotemporal coupling effects in ultrashort pulses and their visualization [10089-17] 
1008900 Suppression of noise of soliton pulses using a polarization-imbalanced nonlinear loop mirror [10089-23]

10089 OP Single shot diagnostic for ultrashort pulses from optical parametric oscillators [10089-25]

POSTER SESSION

10089 OR Analysis and enhancement of 3D shape accuracy in a single-shot LIDAR sensor [10089-24]

10089 OS Towards autonomous photonic reservoir computer based on frequency parallelism of neurons [10089-27] 


\title{
Authors
}

Numbers in the index correspond to the last two digits of the seven-digit citation identifier (CID) article numbering system used in Proceedings of SPIE. The first five digits reflect the volume number. Base 36 numbering is employed for the last two digits and indicates the order of articles within the volume. Numbers start with 00, 01, 02, 03, 04, 05, 06, 07, 08, 09, 0A, 0B...0Z, followed by 10-1Z, 20-2Z, etc.

\author{
Akrout, Akram, OS \\ Álvarez-Tamayo, R. I., 00 \\ Andrés, M., 00 \\ Antonik, Piotr, OS \\ Armas-Rivera, I., 00 \\ Asghari, Mohammad H., OA \\ Beltrán-Pérez, G., 00 \\ Bennett, Corey V., OF, OG \\ Bielawski, Serge, 02, 03 \\ Borysenko, Andrii, 02 \\ Bracamontes-Rodriguez, Y. E., 00 \\ Brubach, Jean-Blaise, 02 \\ Carrascosa, A., 00 \\ Cassinari, Lodovico, 02 \\ Catenacci, Jared, OG \\ Choi, Gudong, OR \\ Couprie, Marie-Emmanuelle, 02 \\ Daykin, Ed P., OF \\ Diels, Jean-Claude, OP \\ Durán-Sánchez, M., 00 \\ El Koussaifi, Rebecca, 03 \\ Evain, Clément, 02, 03 \\ Feng, Tianli, 07 \\ Furukawa, Hideaki, OA \\ Guang, Zhe, OB, Ol \\ Haelterman, Marc, OS \\ Han, Munhyun, OR \\ Hanayama, R., $\mathrm{OH}$ \\ Hänsel, Wolfgang, 07 \\ Harding, Patrick J., OG \\ Hiller, Nicole, 02 \\ Holzwarth, Ronald, 07 \\ Howard, Marylesa, OG \\ Hsu, Ning, OP \\ Ibarra Escamilla, B., 00 \\ Ishii, $\mathrm{K}$., $\mathrm{OH}$ \\ Iwamoto, A., $\mathrm{OH}$ \\ Jalali, Bahram, OA \\ Kawashima, T., $\mathrm{OH}$ \\ Kitagawa, $\mathrm{Y}_{\text {, }} \mathrm{OH}$ \\ Kobayashi, Tetsuya, OA \\ Konishi, Tsuyoshi, 09 \\ Kostinski, Natalie, OG \\ Kurita, T., $\mathrm{OH}$ \\ Kuroda, Hiroto, 05 \\ Kuzin, E. A., 00 \\ La Lone, Brandon M., OF, OG \\ Labat, Marie, 02 \\ Le Parquier, Marc, 02
}

\author{
Lodes, Adam, OG \\ Makino, Takeshi, OA \\ Man, Wai S., OA \\ Manceron, Laurent, 02 \\ Massar, Serge, OS \\ Mero, Mark, 07 \\ Mheen, Bongki, OR \\ Miura, E., $\mathrm{OH}$ \\ Mori, Y., $\mathrm{OH}$ \\ Müller, Anke-Susanne, 02 \\ Muñoz-Aguirre, S., 00 \\ Nagashima, Tomotaka, 09 \\ Nishimura, $\mathrm{Y} ., \mathrm{OH}$ \\ Pottiez, O., 00 \\ Raabe, Nils, 07 \\ Randoux, Stephane, 03 \\ Rhodes, Michelle A., OB, OF, OG, Ol \\ Ricaud, Jean-Paul, 02 \\ Roussel, Eléonore, 02 \\ Roy, Pascale, 02 \\ Sakagami, $\mathrm{H}$., $\mathrm{OH}$ \\ Sato, N., $\mathrm{OH}$ \\ Schönfeldt, Patrik, 02 \\ Sekine, T., $\mathrm{OH}$ \\ Sell, Alexander, 07 \\ Sentoku, Y., $\mathrm{OH}$ \\ Seo, Hongseok, OR \\ Song, Minhyup, OR \\ Song, Youjian, 07 \\ Steinmann, Johannes Leonard, 02 \\ Steinmeyer, Günter, 07 \\ Sunahara, A., $\mathrm{OH}$ \\ Suret, Pierre, 03 \\ Suzuki, Masayuki, 05 \\ Szwaj, Christophe, 02, 03 \\ Tian, Haochen, 07 \\ Tikan, Alexey, 03 \\ Tordeux, Marie-Agnès, 02 \\ Trebino, Rick, OB, OI \\ Trinh, Paul, OA \\ Tsang, Kwong Shing, OA \\ Wada, Naoya, OA \\ Wang, Xiaomin, $\mathrm{OA}$ \\ Yamasaki, Yu, 09 \\ Yoneya, Shin, 05 \\ Younk, Patrick W., OF, OG \\ Zach, Armin, 07 \\ Zhu, Ping, $O B$
}


Proc. of SPIE Vol. 10089 1008901-6

Downloaded From: https://www.spiedigitallibrary.org/conference-proceedings-of-spie on 25 Apr 2023 Terms of Use: https://www.spiedigitallibrary.org/terms-of-use 


\section{Conference Committee}

Symposium Chairs

Reinhart Poprawe, Fraunhofer-Institut für Lasertechnik (Germany)

Koji Sugioka, RIKEN (Japan)

Symposium Co-chairs

Guido Hennig, Daetwyler Graphics AG (Switzerland)

Yongfeng Lu, University of Nebraska-Lincoln (United States)

Program Track Chairs

Vladimir Ilchenko, OEwaves, Inc. (United States)

Paul O. Leisher, Rose-Hulman Institute of Technology (United States)

Conference Chairs

Bahram Jalali, University of California, Los Angeles (United States)

Daniel R. Solli, University of California, Los Angeles (United States) and Georg-August-Universität Göttingen (Germany)

Sergei K. Turitsyn, Aston University (United Kingdom)

Günter Steinmeyer, Max Born Institute for Nonlinear Optics and Short Pulse Spectroscopy (Germany)

Neil G. R. Broderick, The University of Auckland (New Zealand)

Conference Program Committee

Nail Akhmediev, The Australian National University (Australia)

Mohammad H. Asghari, University of California, Los Angeles (United States)

Jason T. Chou, Lawrence Livermore National Laboratory (United States)

John M. Dudley, FEMTO-ST, Université de Franche - Comté, CNRS (France)

Goëry Genty, Tampere University of Technology (Finland)

Michael Hanache, National Security Technologies, LLC (United States)

Georg Herink, Georg-August-Universität Göttingen (Germany)

Claus Ropers, Georg-August-Universität Göttingen (Germany)

Majid Taki, Université des Sciences et Technologies de Lille (France)

Paul D. Trinh, Time Photonics, Inc. (United States)

Chao Wang, University of Kent (United Kingdom) 


\section{Session Chairs}

1 Laser Transients and Electron Beam Dynamics

Daniel R. Solli, University of California, Los Angeles (United States)

2 Real-time Techniques

Georg Herink, Georg-August-Universität Göttingen (Germany)

3 Photon Doppler Velocimetry and Ranging

Bahram Jalali, University of California, Los Angeles (United States)

4 Nonlinear Dynamics and Measurements I

Paul D. Trinh, Time Photonics, Inc. (United States)

5 Nonlinear Dynamics and Measurements II

Mohammed H. Asghari, University of California, Los Angeles

(United States) 